\title{
Impact of promoting employment quality on new generation migrant workers' settlement intention a study based on gender perspective
}

\author{
Longmei $\operatorname{Sun}^{1}$ \\ ${ }^{1}$ College of Business Administration, Shandong Women's University, China
}

\begin{abstract}
This meta-analysis summarizes the research findings of many local and international experts and constructs a comprehensive employment quality evaluation system based on factors including monthly salary, working hours, job stability, career reputation, social security, labor rights, development prospective, worker satisfaction and more. Binary Logistic Regression was used to analyze and discuss new generation migrant workers' settlement intention, both as a whole and for different genders. Analysis suggests there are significant gender differences when it comes to settlement intention. Education level, social circle, skill development, weekly working hours and colleague relationship all have profound impact on new generation female migrant workers' settlement intention. On the other hand, only career type and overall job satisfaction show significant influence over male migrant workers' decision. It has to be noted that overall job satisfaction is an integrative indicator. Therefore, this paper suggests that in order to study the relationship between employment and settlement intention, one should start from analyzing comprehensive employment quality indicators with special attention paid to gender differences.
\end{abstract}

\section{Introduction}

New generation migrant workers are defined as people who were born after 1980, currently employed in the city, but still hold the rural census registers. Since 2018, new generation migrant workers had made up more than half of the total migrant worker population. Net migration population, consisted of mostly new generation migrant workers, is one of the major contributing factors to further urbanisation. The future settlement of new generation migrant workers is a critical aspect of accelerating urbanization progress as well as improving the extent and quality of urbanization of our nation.

Employment, as the basis to migrant workers' city lives, has definitive links to settlement intention. Employment quality of migrant workers is a vital issue that affects migrant workers' self-development, rural development, city building, national progress as well as social stability. However, due to the long-standing reality of excessive supply in Chinese labour market, Chinese researchers focused much less on employment quality than employment quantity and only started at a much later time. In spite of that, due to recent changes in the demand and supply structure, migrant workers started to demand more than fulfilling their most basic needs, which drew attention to the quality of employment of migrant workers. Therefore, a study on settlement intention needs to take into consideration many aspects of employment quality.

\section{Literature Review and Research Hypothesis}

\subsection{Research on migrant workers' settlement intention and employment quality}

Settlement intention is also known as willingness to settle down long-term in the city. International researches often define it as intention of 'permanent relocation'. Chinese researchers had produced a myriad of findings on migrant workers' settlement intention, mostly about description of migrant workers' settlement intention and factors determining settlement intention. In general, an increasing trend in migrant workers' settlement intention with time has been observed. For example, in Fujian province, the percentage of migrant workers that were willing to settle down in the city increased from $25 \%$ in the year 2002 to $39.3 \%$ in the year 2006[1]. Based on questionnaires done by a project group from Nankai University in 2013, Researcher Liang Tukun discovered that $44.4 \%$ of new generation migrating population were willing to settle down in the city[2]. Researches on factors determining settlement intention encompasses a wide range of topics, including socioeconomic demographic variables, professional experiences, migrating history, urban dwelling, and integration as well as public services. These researches provide vital references for our investigation into migrant workers' settlement intention and its influencing factors. 
Researches on employment quality started in the year 1999, after the International Labour Organization, ILO, first established the concept of 'Decent work' and its relevant basic indicators. Currently, many researchers define employment quality via multi-dimensional summaries. This article references previous research findings, selecting eight indicators to measure the employment quality of migrant workers, namely salary income, working hours, job stability, career reputation, social security, labour rights, development prospective and worker satisfaction.

\subsection{Researches on links between employment quality settlement intention, gender prespectives and theoretical hypothesis}

The influence of employment on settlement intention has been extensively researched. Most papers only investigate the relationship between partial employment quality indicator variables and settlement intention, while failing to include comprehensive employment quality indicators system. For example, Huang Qian showed that factors like employment status and monthly income have significant impact on the settlement intention of migrating population[3]. Su Qun and Li Xiao discovered that stable employment and secured livelihood can drastically increase settlement intention[4]. Meanwhile, it was also found that involvement in medical insurance and pension system, acquisition of vocational certificates and job promotions greatly motivate the new generation of migrant workers to enter and stay in the city. Gong Ziyu systematically studied the impact of employment quality on migrant workers' acclimatization to city lives and found that the presence of a union, weekly working hours, job satisfaction and perceived social fairness all have positive impacts on settlement intention while experiences with wage arrears hinder settlement intention, however, gender differences were not included in his study[5].

Some researchers have noticed gender differences in migrant workers and thus completed related researches. However, few has investigated the gender differences in the influence of systematic employment quality over migrant workers settlement intention. Thus, further studies are needed to investigate the gender differences in the influence of employment quality over migrant workers' settlement intention.

These researches provided vital references for our investigation into the influence of employment quality over settlement intention. There are two major shortcomings of current researches. Firstly, these researches did not involve enough employment quality indicators to be systematic and therefore unable to comprehensively reveal the actual link between employment quality and new generation migrant workers' settlement intention. Secondly, few studies separated the subjects into different gender groups and therefore lack in gender difference analysis.

Taking into consideration of shortcomings in existing researches, this article will expand and creatively analyze in two aspects.

Firstly, this article attempts to consider the systematic employment quality as a whole and thus evaluate its impact on new generation migrant workers' settlement intention to reflect the actual link between them. Secondly, using new generation migrant workers as research subjects, we further conduct layered studies based on different genders. This will help to identify the true differences between genders in real life, therefore assisting in policymaking.

Based on research goals and the discussions above, we propose the following basic research hypotheses:

Improvement in new generation migrant workers' employment quality can increase their settlement intention.

Gender differences exist in the influence of new generation migrant workers' employment quality over settlement intention.

\section{Data, Variables and Methodology}

\subsection{Sources of data}

This paper cites data obtained from questionnaires "Questionnaire on New Generation Migrant Workers' Settlement Intention" conducted in 2020 by students of Shandong Women's University, specifically all the students are of Shandong province origin. The targets of the questionnaires are individuals of the following characteristics "born after the year 1980, employed or running a business in the city but still holding rural register". The questionnaires were disseminated online and a total of 341 responses were collected. Several responses were excluded due to violation of age restriction and in the end, 273 responses were included in the modelling. Out of the 273 responses, $53.8 \%$ are male and $46.2 \%$ are female. The ratio is suitable for analysis. Meanwhile, inspection of responses suggests that responders span across different age groups, education level, years spent in the city, regions, and area of movement and therefore representative of new generation migrant workers.

\subsection{Choice of Variables}

\subsubsection{Dependent Variable: Statistical Description of Settlement Intention}

The dependent variable of choice is 'settlement intention', a subjective attitude, evaluated by the question 'Are you willing to settle down in the city that you are currently working in?' The choices include (1)Yes; (2)No for the time being; (3Have not considered that; (4)No. In this article, we group the responses into two categories: 'Yes' (Choice (1) and 'No' (Choice (2)(3) (4))

\subsubsection{Independent Variable: Employment Quality}

The independent variable of choice is employment quality, including salary income, working hours, job stability, career reputation, social security, labour rights, career development and worker satisfaction.

\subsubsection{Objective Indicators}


Salary income' is measured by the average monthly income (including basic wage, bonuses, overtime pay and etc).

'Working hours' is measured by the number of working hours per week. It is divided into five categories: 'fewer than 40 hours'; '41-44 hours'; '45-48 hours'; '49-56 hours'; 'above 57 hours'.

Table1. Data collected in the "Questionnaire on New Generation Migrant Workers' Settlement Intention"

\begin{tabular}{|c|c|c|c|c|c|c|c|}
\hline \multirow{2}{*}{ Variables } & \multirow{2}{*}{ Assigned Value } & \multicolumn{2}{|c|}{ Total } & \multicolumn{2}{|c|}{ Female } & \multicolumn{2}{|c|}{ Male } \\
\hline & & Average & $S D$ & Average & $S D$ & Average & $S D$ \\
\hline $\begin{array}{l}\text { Monthly Salary } \\
\text { Income }\end{array}$ & & 4950.18 & 2749.403 & 4413.49 & 2460.418 & 5410.20 & 2904.885 \\
\hline $\begin{array}{l}\text { Weekly Working } \\
\text { Hours } \\
\end{array}$ & $\begin{array}{c}\text { Less than or equal to } 40 \mathrm{hr}=5 ; 41-44 \mathrm{hr}=4 ; 45-48 \mathrm{hr}=3 ; 49- \\
56 \mathrm{hr}=2 ; \text { more than or equal to } 57 \mathrm{hr}=1\end{array}$ & 2.95 & 1.318 & 3.17 & 1.167 & 2.75 & 1.409 \\
\hline Contract Type & $\begin{array}{c}\begin{array}{c}\text { Permanent }=4 ; \text { Fixed Term }=3 ; \text { By Project }=2 ; \\
\text { Contractor }=1 ; \text { Self-employed }=5\end{array} \\
\end{array}$ & 2.71 & 1.195 & 2.67 & 1.057 & 2.74 & 1.304 \\
\hline $\begin{array}{c}\text { Nature of } \\
\text { employment }\end{array}$ & $\begin{array}{c}\text { Privately owned SME }=1 ; \text { Privately owned renown } \\
\text { companies }=2 ; \text { State owned companies }=3 ; \\
\text { Party/Government/Organization/Military=4; Home } \\
\text { Business }=5\end{array}$ & 2.95 & 1.746 & 2.96 & 1.750 & 2.94 & 1.749 \\
\hline Job Type & $\begin{array}{c}\text { Management }=3 ; \text { Technician }=3 \text {; Desk Worker }=2 ; \\
\text { Manufacture and transport worker }=1 ; \text { Employed in } \\
\text { service industry }=1 ; \text { Self-employed }=4\end{array}$ & 2.19 & 1.070 & 2.06 & 1.049 & 2.29 & 1.080 \\
\hline Insurance & Yes $=1 ; \mathrm{No}=0$ & .74 & .439 & .76 & .428 & .72 & .450 \\
\hline Voluntariness & $\mathrm{Yes}=1 ; \mathrm{No}=0$ & .48 & .501 & .47 & .501 & .49 & .502 \\
\hline Unfair Treatment & $\mathrm{Yes}=1 ; \mathrm{No}=0$ & .40 & .491 & .36 & .481 & .44 & .498 \\
\hline $\begin{array}{c}\text { Satisfaction with } \\
\text { training } \\
\text { opportunity } \\
\end{array}$ & Satisfied $=3$, Neutral $=2$, Unsatisfied $=1$ & .42 & .494 & .43 & .497 & .41 & .493 \\
\hline $\begin{array}{l}\text { Probability for } \\
\text { promotion and } \\
\text { wage increase }\end{array}$ & Satisfied $=3$, Neutral $=2$, Unsatisfied $=1$ & 2.36 & .671 & 2.39 & .632 & 2.33 & .704 \\
\hline $\begin{array}{c}\text { Satisfaction with } \\
\text { working } \\
\text { environment }\end{array}$ & Satisfied $=3$, Neutral $=2$, Unsatisfied $=1$ & 2.13 & .736 & 2.17 & .658 & 2.10 & .797 \\
\hline $\begin{array}{c}\text { Satisfaction with } \\
\text { colleague relations }\end{array}$ & Satisfied $=3$, Neutral $=2$, Unsatisfied $=1$ & 2.29 & .677 & 2.33 & .620 & 2.26 & .722 \\
\hline $\begin{array}{c}\begin{array}{c}\text { Satisfaction with } \\
\text { higher and lower } \\
\text { ranks }\end{array} \\
\end{array}$ & Satisfied $=3$, Neutral $=2$, Unsatisfied $=1$ & 2.56 & .598 & 2.56 & .586 & 2.56 & .609 \\
\hline $\begin{array}{c}\text { Overall } \\
\text { work satisfaction }\end{array}$ & Satisfied $=3$, Neutral $=2$, Unsatisfied $=1$ & 2.48 & .653 & 2.52 & .603 & 2.45 & .694 \\
\hline \multicolumn{8}{|l|}{ Control Variables } \\
\hline Gender & Male $=1 ;$ Female $=0$ & .54 & .499 & .00 & .000 & 1.00 & .000 \\
\hline Age & & 31.64 & 5.538 & 31.14 & 5.520 & 32.06 & 5.536 \\
\hline Marital Status & Married $=1 ;$ Otherwise $=0$ & 2.30 & .793 & 2.41 & .751 & 2.20 & .816 \\
\hline Education Level & Lower Secondary $=1$; Upper Secondary $=2$; Tertiary $=3$ & .63 & .485 & .64 & .481 & .61 & .489 \\
\hline Training Level & $\mathrm{No}=0 ; \mathrm{Yes}=1$ & 2.32 & 1.147 & 2.09 & .955 & 2.52 & 1.257 \\
\hline $\begin{array}{l}\text { Years spent as } \\
\text { a non-farmer }\end{array}$ & $\begin{array}{c}\text { Fewer than } 2 \text { years }=1 ; 3 \text { to } 5 \text { years }=2 ; 6-10 \text { years }=3 ; 11 \text { to } \\
15 \text { years }=4 ; \text { more than } 15 \text { years }=5\end{array}$ & 2.20 & .970 & 2.31 & .934 & 2.11 & .994 \\
\hline Work Location & $\begin{array}{c}\text { Province } \text { Capital=1; Prefectural-Level City }=2 ; \text { County }=3 ; \\
\text { Others }=4\end{array}$ & 2.55 & 1.077 & 2.79 & 1.014 & 2.34 & 1.089 \\
\hline Area of Movement & $\begin{array}{c}\text { Inter-Province }=1 ; \text { Inter-City }=2 ; \text { Intra-City }=3 ; \text { Intra- } \\
\text { County }=4\end{array}$ & .54 & .499 & .00 & .000 & 32.06 & 5.536 \\
\hline
\end{tabular}

'Career reputation' is represented by 'nature of employment'and 'job type'. 'nature of employment'takes privately owned small-medium companies as reference and ranks the party/government/organization/military as the highest. For 'job type', according to table 1, we divided all jobs (except private company owners and selfemployed) into blue collar (assigned value of 1), white collar (assigned value of 2) and premium white collar (assigned value of 3 ).

'Social security' is measured by whether the individual possesses the five government-enforced insurances and additional commercial insurances.

'Labor rights' is gauged by experiences with 'unfair treatment' and 'non-voluntary work'.

'Career development' includes 'satisfaction with training opportunity' and 'probability of promotion and wage increase'. These two variables are measured with a 5-point scale. Higher score corresponds to greater employment quality.

\subsubsection{Subjective Indicators}

Subjective indicators of employment quality, including 'satisfaction with working environment', 'satisfaction with co-worker relationships' and 'overall employment satisfaction', seek to describe migrant workers' subjective feeling about their current jobs. The questions are directly asked in the questionnaires with a 5-point scale. Similarly, higher score means greater employment quality. Certain modifications are made in the modelling process and can be seen explained in table 1 .

\subsubsection{Control: Population and Migration Variables}

Control includes gender, age, marital status, education level, training level, years spent in city, working location, area of movement and other population and migration variables. Basic information regarding these variables are tabulated in table 1 . 


\subsection{Methodology}

Data processing for this article was done using SPSS 22, primarily adopting descriptive statistical analysis, difference analysis and regression analysis. Firstly, using descriptive analysis to compare study the employment quality and settlement intention of female and male new generation migrant workers. Following that, binary Logistic regression model was adopted to analyze the influence of employment quality indicators over migrant workers' settlement intention. Finally, the article concludes in discussion of the gender differences between the impact of employment quality indicators on settlement intention of male and female migrant workers. The research hypotheses were tested individually. This article explains the relevant research findings and models and, in the end, verifies the proposed hypotheses.

\section{Research Finidings}

\subsection{Comparison of employment quality and settlement intention between genders}

Upon performing gender difference comparison to employment quality variables, it is found that significant gender differences $(\mathrm{p}<0.1)$ exist in salary income, weekly working hours, contract type, childbirth insurance, probability of promotion and wage increase as well as satisfaction with working environment while being insignificant in other variables. Table 2 compares the variables with significant gender differences and the following trends are spotted.

Female migrant workers have a lower average monthly salary income of 4413 yuan as compared to male migrant workers' 5410 yuan. Higher percentage of male migrant workers work more than 48 hours per week and higher percentage of female migrant workers work fewer than 48 hours per week, suggesting that male female workers, on average, work more hours per week than their female counterparts. More females (54.8\%) take up fixed term contracts than males $(38.8 \%)$ while more males $(15.0 \%)$ are self-employed than females $(7.1 \%)$. Females have higher childbirth than males. Interestingly, male migrant workers experience far more dispersed probability of promotion and wage increase, getting a higher percentage in both high probability and low probability than females. In term of satisfaction with working environment, both genders express a high level of satisfaction but more males $(16.3 \%)$ feel discontented than females $(7.9 \%)$.

Table 3 shows that new generation migrant workers have high overall settlement intention. 58.6\% answered 'Yes' to the question 'Are you willing to settle down in the city that you are currently working in?', exceeding the $50 \%$ mark. Meanwhile, female migrant workers $(67.5 \%)$ have higher settlement intention than their male counterparts
(51\%). There exists significant gender difference in settlement intention $(\mathrm{p}<0.01)$.

Table2. Gender Comparison of New Generation Migrant Workers' Employment Quality

\begin{tabular}{|c|c|c|c|c|}
\hline \multicolumn{2}{|c|}{ Variables } & Female & Male & F-Test \\
\hline \multirow{2}{*}{$\begin{array}{l}\text { Monthly } \\
\text { Salary } \\
\text { Income }\end{array}$} & Average & 4413.49 & 5410.20 & \multirow[t]{2}{*}{$9.185 * * *$} \\
\hline & SD & 2460.418 & 2904.885 & \\
\hline \multirow{5}{*}{$\begin{array}{l}\text { Weekly } \\
\text { Working } \\
\text { Hours }\end{array}$} & $>=57$ hours & $7.9 \%$ & $23.1 \%$ & \multirow[t]{5}{*}{$20.544 * * *$} \\
\hline & 49-56 hours & $20.6 \%$ & $27.9 \%$ & \\
\hline & $45-48$ hours & $33.3 \%$ & $17.0 \%$ & \\
\hline & 41-44 hours & $22.2 \%$ & $15.0 \%$ & \\
\hline & $<=40$ hours & $15.9 \%$ & $17.0 \%$ & \\
\hline \multirow{5}{*}{$\begin{array}{l}\text { Contract } \\
\text { Type }\end{array}$} & Permanent & $4.8 \%$ & $6.8 \%$ & \multirow[t]{5}{*}{$8.735 * *$} \\
\hline & Fixed Term & $54.8 \%$ & $38.8 \%$ & \\
\hline & Project & $15.1 \%$ & $16.3 \%$ & \\
\hline & Contractor & $18.3 \%$ & $23.1 \%$ & \\
\hline & $\begin{array}{c}\text { Self- } \\
\text { Employed }\end{array}$ & $7.1 \%$ & $15.0 \%$ & \\
\hline $\begin{array}{l}\text { Maternity } \\
\text { Insurance }\end{array}$ & Yes & $38.1 \%$ & $25.9 \%$ & $4.714 * * *$ \\
\hline \multirow{3}{*}{$\begin{array}{l}\text { Probability } \\
\text { for } \\
\text { promotion } \\
\text { and } \\
\text { wage } \\
\text { increase }\end{array}$} & Low & $14.3 \%$ & $27.2 \%$ & \multirow[t]{3}{*}{$10.738 * * *$} \\
\hline & Moderate & $54.0 \%$ & $36.1 \%$ & \\
\hline & High & $31.7 \%$ & $36.7 \%$ & \\
\hline \multirow{3}{*}{$\begin{array}{l}\text { Satisfaction } \\
\text { with } \\
\text { working } \\
\text { environment }\end{array}$} & Unsatisfied & $7.9 \%$ & $16.3 \%$ & \multirow[t]{3}{*}{$5.129 *$} \\
\hline & Neutral & $50.8 \%$ & $41.5 \%$ & \\
\hline & Satisfied & $41.3 \%$ & $42.2 \%$ & \\
\hline
\end{tabular}

Table3. Gender Comparison of New Generation Migrant Workers' Settlement Intention

\begin{tabular}{|c|c|c|c|c|}
\hline $\begin{array}{c}\text { Sample } \\
\text { Type }\end{array}$ & Number & Yes & No & F-Test \\
\hline Female & 126 & $67.5 \%$ & $32.5 \%$ & \multirow{3}{*}{$7.559 * * *$} \\
\hline Male & 147 & $51.0 \%$ & $49.0 \%$ & \\
\hline Total & 273 & $58.6 \%$ & $41.4 \%$ & \\
\hline
\end{tabular}

\subsection{Logistic regression modelling and result analysis}

We established three individual regression models using all samples, female samples and male samples, Model 1, Model 2 and Model 3, respectively. Using single-variable filtering and multi-variable filtering, we picked variables that are statistically meaning for settlement intention to assemble the final model. In multi-variable regression process, stepwise regression is adopted. The criterion for a variable to be included in the model is sig-value of 0.1 while removed variables have sig-value of 0.15 . Regression results can be seen in Table 4 .

Table4. Logistics Model of influencing factors of new generation migrant workers' settlement intention

\begin{tabular}{|c|c|c|c|c|c|c|c|c|c|}
\hline & \multicolumn{3}{|c|}{ Model1 } & \multicolumn{3}{|c|}{ Model2 (Female) } & \multicolumn{3}{|c|}{ Model3 (Male) } \\
\hline & $B$ & Sig. & $\operatorname{Exp}(B)$ & $B$ & Sig. & $\operatorname{Exp}(B)$ & $B$ & Sig. & $\operatorname{Exp}(B)$ \\
\hline Gender & -.730 & .027 & .482 & & & & & & \\
\hline Education Level & & & & & .018 & & & & \\
\hline
\end{tabular}




\begin{tabular}{|c|c|c|c|c|c|c|c|c|c|}
\hline Education Level (1) & & & & 1.029 & .184 & 2.799 & & & \\
\hline Education Level (2) & & & & $2.131 * * *$ & .005 & 8.420 & & & \\
\hline Skill Training & $-1.098 * * *$ & .001 & .334 & $-1.088^{*}$ & .051 & .337 & & & \\
\hline Area of Movement & & .014 & & & .001 & & & & \\
\hline Area of Movement (1) & $.758^{*}$ & .083 & 2.134 & -.781 & .356 & .458 & & & \\
\hline Area of Movement (2) & $1.333 * * *$ & .002 & 3.794 & $2.230^{* * *}$ & .008 & 9.303 & & & \\
\hline Area of Movement (3) & $1.221 * * *$ & .009 & 3.391 & $1.798 * *$ & .035 & 6.036 & & & \\
\hline Weekly Working Hours & & .044 & & & .013 & & & & \\
\hline Weekly Working Hours (1) & .575 & .244 & 1.777 & 1.429 & .187 & 4.173 & & & \\
\hline Weekly Working Hours (2) & .383 & .462 & 1.466 & 1.642 & .107 & 5.163 & & & \\
\hline Weekly Working Hours (3) & -.759 & .158 & .468 & -.826 & .409 & .438 & & & \\
\hline Weekly Working Hours (4) & .089 & .877 & 1.093 & 1.321 & .232 & 3.749 & & & \\
\hline Job Type & & & & & & & & .099 & \\
\hline Job Type (1) & & & & & & & -.278 & .642 & .757 \\
\hline Job Type (2) & & & & & & & -.495 & .285 & .610 \\
\hline Job Type (3) & & & & & & & $1.212 *$ & .081 & 3.360 \\
\hline $\begin{array}{c}\text { Satisfaction with training } \\
\text { opportunity }\end{array}$ & & .103 & & & & & & & \\
\hline $\begin{array}{c}\text { Satisfaction with training } \\
\text { opportunity (1) }\end{array}$ & $1.180^{*}$ & .053 & 3.255 & & & & & & \\
\hline $\begin{array}{l}\text { Satisfaction with training } \\
\text { opportunity (2) }\end{array}$ & $1.398^{* *}$ & .035 & 4.047 & & & & & & \\
\hline $\begin{array}{c}\text { Probability of promotion and } \\
\text { wage increase }\end{array}$ & & .090 & & & & & & & \\
\hline $\begin{array}{c}\text { Probability of promotion and } \\
\text { wage increase (1) }\end{array}$ & .186 & .653 & 1.205 & & & & & & \\
\hline $\begin{array}{c}\text { Probability of promotion and } \\
\text { wage increase (2) }\end{array}$ & $.876^{*}$ & .054 & 2.402 & & & & & & \\
\hline $\begin{array}{l}\text { Satisfaction with colleague } \\
\text { relations }\end{array}$ & & & & & .001 & & & & \\
\hline $\begin{array}{l}\text { Satisfaction with colleague } \\
\text { relations (1) }\end{array}$ & & & & 1.054 & .320 & 2.869 & & & \\
\hline $\begin{array}{l}\text { Satisfaction with colleague } \\
\text { relations (2) }\end{array}$ & & & & $3.045^{* * *}$ & .008 & 21.014 & & & \\
\hline Overall Job Satisfaction & & .000 & & & & & & .000 & \\
\hline Overall Job Satisfaction (1) & -.065 & .900 & .937 & & & & .820 & .205 & 2.272 \\
\hline Overall Job Satisfaction (2) & $1.607^{* *}$ & .005 & 4.990 & & & & $2.646^{* * *}$ & .000 & 14.097 \\
\hline Constant & -1.923 & .007 & .146 & -4.151 & .010 & .016 & -1.459 & .011 & .233 \\
\hline
\end{tabular}

\subsection{Model 1 result analysis}

Model 1 suggests 7 variables including gender, skill training, area of movement, weekly working hours, satisfaction with training opportunity, probability of promotion and wage increase as well as overall work satisfaction remain in the model, having significant impact on new generation migrant workers' settlement intention. Firstly, female migrant workers have significantly higher settlement intention than their male counterparts $(p<0.05)$. Secondly, training opportunity has no appreciable impact on settlement intention. Thirdly, weekly working hours have significant impact on settlement intention, but the correlation is non-monotonic. The highest level of settlement intention is found in the '49-56 hours' group while the lowest is found in the '41-44 hours' group. Therefore, it suggests that increasing employment quality by reducing working hours does not help in promoting settlement intention. This phenomenon is likely attributed to the strong link between weekly working hours and other factors like salary income and being able to take care of family members. Fourthly, increasing satisfaction with training opportunity can promote settlement intention. The higher the satisfaction, the greater the settlement intention. Fifthly, increasing probability of promotion and wage increase can promote settlement intention. Taking the group with 'unlikely to get a promotion and wage increase' as the base level, the group with 'moderate change of getting a promotion and wage increase' and the group with 'quite likely to get a promotion and wage increase' have 1.205 and 2.402 times the settlement intention respectively. Lastly, increasing overall work satisfaction can elevate settlement intention. The group with 'satisfied' response has, on average, 4.990 times the settlement intention of the group with 'not satisfied' response. This impact is especially significant.

The other variables have been removed from the model and therefore not explained.

Therefore, hypothesis 1 'Improvement in new generation migrant workers' employment quality can increase their settlement intention' can only be partially verified.

\subsubsection{Model 2 result analysis}

Model 2 shows that, for new generation female migrant 
workers, education level, skill training, area of movement, weekly working hours and satisfaction with co-worker relationships have significant influence on settlement intention. Firstly, compared with the group that only received up to lower secondary school education, the group that received upper secondary school education and the group that received tertiary education has, on average, 2.799 times and 8.420 times of the settlement intention, marked increase from the contrast group. Secondly, the result is similar to Model 1 for skill training. Thirdly, weekly workings hours have significant impact on female migrant workers' settlement intention. Compared to the group with' more than 57 hours per week', as the number of working hours decreases, the settlement intention shows a non-monotonic increase similar to Model 1, with larger inter-group differences. Fourthly, comparing to the group with 'not satisfied' response, as the level of satisfaction increases, a monotonic increasing trend can be observed., culminating in a drastic increase in settlement intention in the group with 'satisfied' response, being 21.014 times of the 'not satisfied' group.

In Model 2, the variable 'weekly working hours' has meaningful gender differences, having larger impact on females than males. Meanwhile, the other variable 'satisfaction with co-worker relationships' has no noticeable gender differences.

\subsubsection{Model 3 result analysis}

Model 3 shows that, for male migrant workers, only 'job type' and 'overall worker satisfaction' remain in the model. Firstly, for new generation male migrant workers, job type has significant impact to settlement intention $(p<0.1)$. As compared to 'worker and service personnel', individuals who are self-employed or run a privately owned company have 3.360 times the settlement intention. The difference between other groups is insignificant. Secondly, for overall workers satisfaction, the groups that answered 'neutral' and 'satisfied', on average, have 2.272 times and 14.097 times the settlement intention of the group that answered, 'not satisfied'. Therefore, increasing overall worker satisfaction can monotonically increase new generation male migrant workers' settlement intention. This is especially prominent for the 'satisfied' group $(p=0.000)$.

The two employment quality variables in Model 3 do not exhibit significant gender differences.

To sum up, Model 2 and Model 3 fully verify Hypothesis 2 'Gender differences exist in the influence of new generation migrant workers' employment quality over settlement intention' and partially verify that Hypothesis 1' Improvement in new generation migrant workers' employment quality can increase their settlement intention.

\section{Conclusion and Recommendations}

\subsection{Summary}

Firstly, among the employment quality indicators, 'satisfaction with training opportunity', 'probability of promotion and wage increase' and 'overall worker satisfaction' are all positively related to settlement intention of new generation migrant workers. Improvement in these aspects can drastically increase workers' settlement intention. 'Weekly working hours' also has significant impact on settlement intention, but not conforming to a monotonic relationship. The rest of the employment quality variables does not exhibit significant impact on settlement intention.

Secondly, there exist significant gender differences in settlement intention among new generation migrant workers. These differences could be attributed to variables with inherited significant gender differences, like 'weekly working hours' or variables without inherited significant gender difference, like 'satisfaction with co-worker relationships', 'job type' and 'overall worker satisfaction'. The later is likely due to different genders putting different degree of emphasis on the variables.

Thirdly, the variable that significant impacts the migrant workers as a whole as well as the male migrant workers, 'overall worker satisfaction' is an integrative indicator. Therefore, it is prone to affected by other employment quality variables. This indicates that the link between employment quality and settlement intention is more complex, simply improving certain employment quality variables might not significantly boost new generation migrant workers' settlement intention. Only systematic upgrade to employment quality to increase 'overall worker satisfaction' can potentially achieve the goal of increasing settlement intention.

To sum up, under current employment environment, improving certain employment quality variables has limited effect of promoting new generation migrant workers' settlement intention. More attention should be paid to the subjective feelings of new generation migrant workers, with a special emphasis on gender differences.

\subsection{Recommendations}

Special attention should be paid to those variables that significant impact settlement intention when studying the influence of employment over new generation migrant workers' settlement intention. One must also note the differences that exist between genders. Only by pinpointing those variables that truly impact settlement intention of migrant workers, can one come up with specific policy suggestions to promote the integration of migrant workers into the city. Some recommendations have been made:

1. Policymakers and employers should correctly identify the impact of different employment quality variables on new generation migrant workers' settlement intention and pay special attention to those with significant influence.

2. Settlement intention can be increased by improving the overall employment quality of new generation migrant workers. Although the majority of the variables analyzed, on its own, has limited impact on settlement intention, an overall increase in employment quality can promote overall workers' satisfaction and subsequently increase settlement intention. The relationship 
between employment quality and overall workers' satisfaction is the focus of our following researches.

3. Emphasis should be put on the gender differences in the impact of employment quality on settlement intention of new generation migrant workers. For male migrant workers, only improving certain employment quality indicators can be insufficient to induce a significant increase in their settlement intention. For female migrant workers, we must meet their specific needs based on their unique characteristics.

\section{ACKNOWLEDGMENT}

This research is sponsored by Shandong "12th Five-Year Plan" Tertiary Institution Humanities and Social Sciences Research Centre(Project Name: Comparison Study of Female Labour Transfer Model for suburbs and rural regions/Project Number: ZD03) as well as Nationwide Women/Gender Study and Education Centre(Shandong Women's University)Open Fund(Project Name: Career Development and Citizenization of New Generation Female Migrant Workers/Project Number: 2014SDJDA05).

Shandong "12th Five-Year Plan" Tertiary Institution Humanities and Social Sciences Research Centre and Nationwide Women/Gender Study and Education Centre (sponsors).

\section{References}

1. W. Chen and Y. Zhu, "Dynamic fluctuation and internal differenences in settlement intention of mobile population".

2. L. Tukun, "Adapting to changes: Investigation of settlement intention of new generation mobile population and releavant policies".

3. Q. Huang, "Determining factors of settlement intention of migrant workers--Based on data collected from five cities".

4. Q. Su and X. Li, 'Impact of migrant workers' capability for citizenization on settlement intention as well as group differences--Based on anaylysis of Chinese labour dynamic data".

5. Z. Gong, "Employment quality, perceived social fairness and settlement intention of migrant workers". 